\title{
FORMATION OF THE MONITORING SYSTEM OF THE REGIONAL MARKET FOR ALCOHOLIC PRODUCTION
}

\author{
Assoc. Prof. PhD. Irina Ruiga, ${ }^{1}$ \\ Assoc. Prof. Tatiana Likhacheva, ${ }^{1}$ \\ Prof. DSc. Zoya Vasilyeva, ${ }^{1}$ \\ Assist. Prof. Lusine Bagdasaryan, ${ }^{1}$ \\ ${ }^{1}$ Siberian Federal University, Russia
}

\begin{abstract}
The article substantiates the topicality of developing the theoretical and methodological bases for threat monitoring in the regional alcoholic beverages market. The need to modernize the regional policy of state regulation of alcohol production in the subjects of the Russian Federation under growing external and internal economic threats has been identified.
\end{abstract}

The assessment of threats to the development of the region as a result of a reduction in the turnover of alcoholic products was conducted using a situational modeling methodology and a set of target indicators. The result of employing the system of indicators is the development of the requirements for economic stimulation and regulatory support aimed at the alcoholic beverages market.

Relative to ensuring the social and economic security of the region the directions on formation of organizational, informational and methodical support for threats monitoring are determined. A new methodology for assessing threats based on the situational modeling makes it possible to develop recommendations for federal and regional public authorities to improve mechanisms for regulating threats aimed at developing the regional alcoholic beverages market by eliminating institutional barriers to market entry for the development of free competition Business, attractive business environment.

The practical significance of the research is timely assessment and prevention of crisis phenomena for increasing the level of social, demographic and economic security of the region.

Keywords: moimgt, threats, regional alcoholic beverages market

\section{INTRODUCTION}

The relevance of the study of threats to the regional alcohol market is determined by the growing role of the state in finding a balance of economic interests and protecting public health.

In recent years, consumption of alcohol-containing beverages in Russia is rapidly declining, for the period 2011-2016. The reduction was almost a third (from 18 to 12.8 
liters per person per year). However, this level does not correspond to the level of permissible alcohol consumption (at the rate of 8 liters of absolute alcohol (anhydrous alcohol) per year per capita) established by the World Health Organization (WHO). According to WHO experts, exceeding the permissible level is extremely dangerous for the health of the nation and consumption beyond this limit of each liter takes 11 months of life in men and 4 months in women. According to world statistics, alcohol consumption accounts for nearly 2 million deaths and 4 percent of diseases worldwide every year [1].

Direct and indirect economic losses from alcoholization of the population cause tangible damage to the socio-economic development of the country. Economic losses include an increased mortality rate, a reduction in the duration of a healthy life, disability, a decrease in labor productivity, the costs of treating diseases associated with alcohol consumption, social transfers to the state of disabled people, orphans, damage from fires, road accidents,

In accordance with the National Security Strategy of the Russian Federation, approved by the Decree of the President of the Russian Federation of December 31, 2015, № 683, improving the quality of life, promoting public health, ensuring a stable demographic development of the country are national interests, and alcoholism is identified as one of the main threats to national security in Sphere of public health services [2].

Thus, alcoholism as one of the factors of the demographic and social crisis in Russia is a national threat and requires the implementation of comprehensive regulation, both at the federal and regional levels.

Over the past decade, the Russian Federation has formed the minimum required package of regulations aimed at preventing alcoholism among the population, as well as regulating various aspects of the alcohol market.

The content of regulatory documents is mostly aimed at a significant reduction in the level of alcohol consumption; Increase the effectiveness of the alcohol abuse prevention system; Increase the effectiveness of alcohol market regulation. Among the main innovations of the period of reforms on the alcohol market (2009-2015), it is worth noting the following:

- increase in excise taxes on alcohol products (strong alcoholic beverages, cognacs, vodka, liquor);

- the need to establish minimum retail prices for vodka;

- increasing the cost of licensing;

- restrictions on sales and advertising.

These reasons led to the rise in prices for alcoholic beverages. In addition to this, in the conditions of a prolonged economic crisis, prices on raw materials rise, the cost of credit resources and the purchasing power of the population decrease. 
As a result of the above-mentioned cause-effect factors, threats to the development of the alcohol market, as well as the economy of the regions of the Russian Federation as a whole:

1. Reducing the number of producers and volumes of alcoholic beverages production.

2. A sharp decline in the market shares of regional producers.

3. Reducing the recognition of regional brands of alcoholic beverages.

4. Termination of the activities of regional enterprises that produced high-quality alcoholic products under their own trademarks

5. Reduction of the economic potential of the alcoholic beverages market and revenues to the regional budget from the production of excisable products.

6. The appearance in the regional market of business entities (large wholesalers), not controlled by regional authorities.

7. Situational problems with importers of alcoholic beverages in connection with the transition to new controls (for example, the lack of excise stamps of the old model, July 2016).

8. Repression of entrepreneurs from the sphere of legal business in the shadow sector.

9. Increased sales of illegal, cheaper and lower-quality products.

10. Increase in the incidence of harm to the health of the population as a result of the use of low-quality / counterfeit products.

Thus, in the current circumstances, the need emerges to develop comprehensive mechanisms for state regulation of production, turnover and retail sales of alcohol products aimed at business development, the filling of regional budgets and the growth of a healthy population.

\section{METHODS AND MATERIALS}

Given the limited powers of the subjects of the Russian Federation in resolving these issues, it is high time to concentrate the efforts of the regional executive authorities to speed up the processes of identifying and preventing offenses, forecasting risk zones for the security of the regional economy and the life of the population; acceleration of the processes of strategic and operational management decisions on the areas of responsibility.

The monitoring system for threats to the regional alcohol market can solve the tasks under consideration.

In general, monitoring means continuous monitoring and recording of object parameters in comparison with specified criteria, constant monitoring of the process with the purpose of revealing its conformity to the desired (planned, target) result [3]. Often monitoring is identified with diagnostics, which is carried out systematically, with 
certain fixed periodicity and using the same system of indicators.

In the scientific and specialized literature, monitoring is also considered as a way of investigating phenomena and processes, which is used in various sciences to reveal the regularities of the dynamics of the state of the objects under study. In practice, monitoring is a management tool that is designed to provide timely and quality information to the process of making managerial decisions. Often in practice, the concept of monitoring is treated more widely - not only as an information support system, but also for the operational regulation of a controlled process (including in the form of a system for automated management of production processes).

To use monitoring in the strategic management system at the regional level, the following basic functions are needed (Table 1).

Table 1 - Functions of monitoring in the system of strategic management on the regional level [4]

\begin{tabular}{|c|c|}
\hline Function & Content \\
\hline Target & $\begin{array}{l}\text { Establishing the purpose of monitoring and criteria for adequacy of results } \\
\text { observation. Achieving a trade-off between accuracy, efficiency and cost of } \\
\text { monitoring }\end{array}$ \\
\hline $\begin{array}{l}\text { Development of a } \\
\text { monitoring model }\end{array}$ & $\begin{array}{l}\text { Establishing the list of target indicators (parameters), to diagnose the state of the } \\
\text { system. Determination of the method for estimation of their values and } \\
\text { instruments, as well as setting the frequency of measurements (observations) }\end{array}$ \\
\hline Rationing & $\begin{array}{l}\text { Finding the trajectory of the normal state of the observation object (the course of } \\
\text { the observed process) and the permissible deviations in the form of target } \\
\text { (normative, planned) values of the measured parameters and their range of } \\
\text { oscillations }\end{array}$ \\
\hline $\begin{array}{r}\text { Measurement } \\
\text { (estimation) }\end{array}$ & $\begin{array}{l}\text { Fixing the current state of the observed process by measuring (estimating) } \\
\text { indicators (indicators, parameters) }\end{array}$ \\
\hline Analysis & $\begin{array}{l}\text { Comparison of the actual and target (normative, planned) trajectory of the } \\
\text { dynamics of the state of the object under observation }\end{array}$ \\
\hline Conclusion & $\begin{array}{l}\text { If the deviation of the actual trajectory from the target (normative, planned) } \\
\text { exceeds the allowed, an announcement is made on the need to make an adequate } \\
\text { managerial decision }\end{array}$ \\
\hline Regulation & $\begin{array}{l}\text { If this function makes a part of the monitoring system, and in case an } \\
\text { inadmissible deviation of the actual against the target (normative, planned) } \\
\text { trajectory of the development dynamics of the observed process on the previous } \\
\text { stage, an optimal decision is made that allows influencing the development of the } \\
\text { observed process, and the subsequent implementation of the decision }\end{array}$ \\
\hline
\end{tabular}

In the opinion of the authors, monitoring of threats to the alcoholic beverages market, mean the procedure for continuous monitoring of the production level, turnover and retail sale of alcoholic products: collection of necessary data; monitoring the dynamics 
of indicators; identification of trends in social, demographic and economic development; forecasting of threats in order to prevent possible damage.

\section{RESULTS}

The estimation of threats and their consequences for the development of the alcohol market should be based on the following principles [5]:

- integrity as the need to analyze all aspects of the research object (sectoral and territorial, social, economic components);

- systemic nature considering both internal interrelations and interdependencies and external factors from the point of view of the object of research as an element of an economic space of a higher level;

- adequacy of the real situation estimation considering the features in the form of conformity criteria for assessing the specificity of the object under study, its retrospective trends;

- variability (alternativeness) as the identification and validity of several options for a way out of the crisis situation, on the one hand, the calculation of trajectories of social, demographic and economic development in the post-stabilization period, on the other hand;

- timely measures to make impact on negative phenomena and processes.

The monitoring of threats to the region's alcoholic beverages market should be aimed at obtaining the response from the state authorities to three basic questions:

1) What is the state of the system (object) under investigation, i.e. to assess the degree of deviation from the norm?

2) What caused this deviation?

3) What are the directions and magnitude of the change in indicators characterizing the state of the alcoholic beverages market are the most optimal in the time period under consideration?

It is obvious that during the transition period monitoring of the interrelations between the scale and speed of the transformation and the emergence of dangerous trends in socio-economic development is to be done. At the disposal of the authorities a toolkit for analyzing potential and real threats to the alcohol market there should always be available with an alternative (scenario) set of solutions to these problems, which allow finding a compromise, to reconcile conflicting interests and trends in the development of society.

The principal difficulty lies in the fact that the Russian Federation does not have a system of indicators for assessing the alcohol market from the standpoint of ensuring the region's alcoholic security. 
In the Concept of Implementing the State Policy on Alcohol Abuse and Prevention of Alcohol Abuse among the Population of the Russian Federation for the Period to 2020, a system for monitoring and analyzing the dynamics of alcohol abuse rates was declared as a priority task [6]. Within the framework of the Concept, indicators are also presented, allowing evaluating the results of the program document. However, there are no thresholds to identify the presence of threats.

According to the authors, the architecture of the main requirements for the monitoring system can be represented as Figure 1 and formulated as follows:

- monitoring of threats to the regional alcohol market is to be based on a system of regional economic interests, business and population interests that do not contradict national interests;

- estimation of threats to the alcohol market at the regional level is to take into account the impact of both external and internal factors;

- the system of estimation indicators should allow assessing the level of threats at least on the basis of several methods;

- in determining threshold values (which can lead to the beginning of negative processes) of threat indicators, it is necessary to take into account the specifics and retrospective trends in the development of the alcohol market in a particular region;

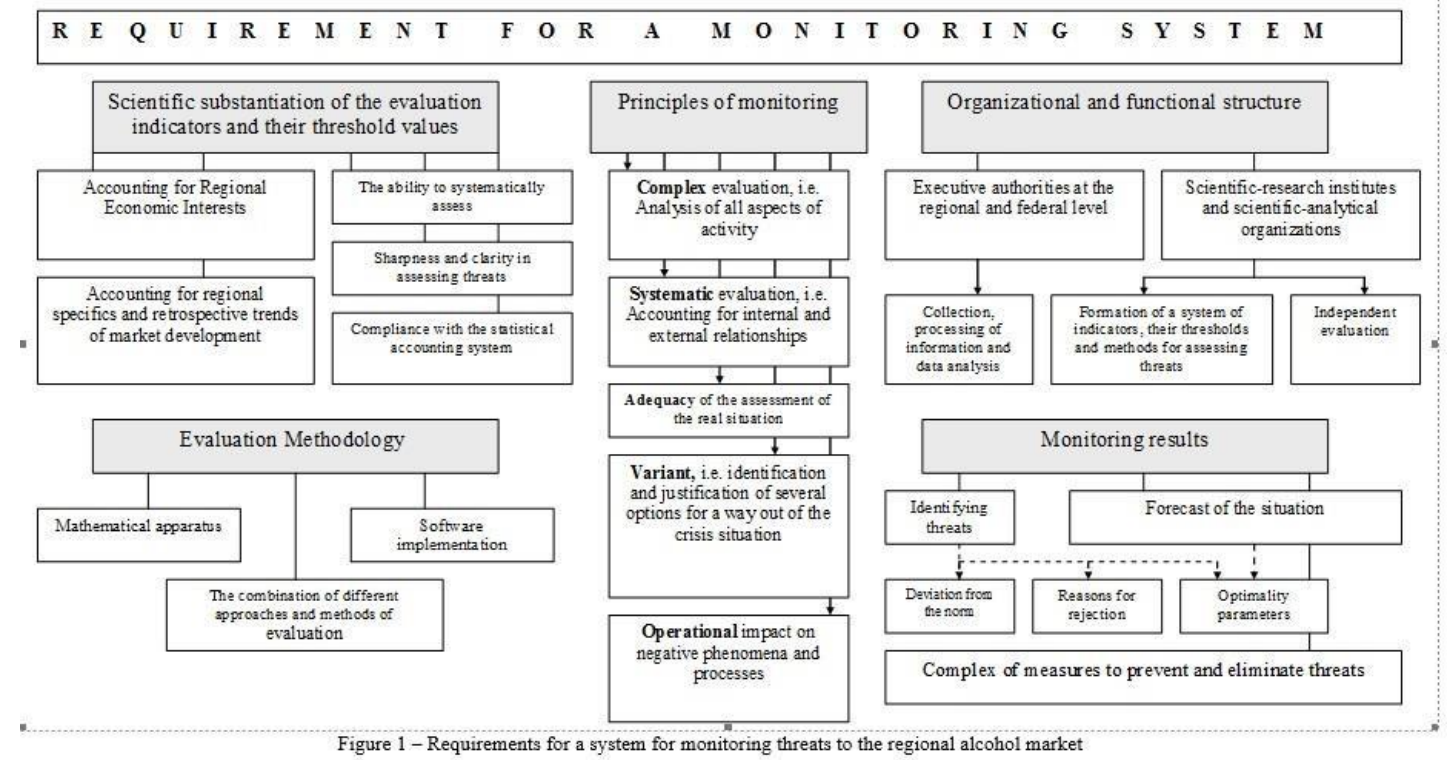

- monitoring should allow timely influence negative phenomena and processes in the economy.

The system of indicators of threats to the regional alcoholic beverages market should be formed in three directions:

1) criteria and indicators of the effectiveness of state regulation of the alcohol market (in accordance with the requirements of Federal Law № 171-FZ of 22.11.1995 “On State Regulation of Production and Turnover of Ethyl Alcohol, Alcoholic and Alcohol- 
Containing Products and on Limiting Consumption (Drinking) of Alcoholic Products" [7]);

2) the system of balanced indicators for the development of the regional alcohol market;

3) the indicators of the effectiveness of preventive measures against alcoholism in the region.

The reliability of the threat estimation depends on the correctness of establishing the quantitative parameters of threshold values. At the same time, the plurality of threshold values, different in their content and character, requires practically the same plurality of methods for calculating them. Depending on the specific economic situation, they must change under the influence of circumstances in the same way as the list of threshold values and methods for calculating them. Of course, the general methodological approaches to the definition of threshold values can and should be sufficiently persistent, concretizing with reference to groups of threshold values that express the essential aspects of the state and development of the alcoholic beverages market.

Most generally presented, the following methodological approaches are used [8]:

- calculation methods, when the calculation is based on natural norms (for example, the average) and thus the threshold values of the indicators are determined;

- method of analogies, when the threshold values are determined in the same ways as in foreign or domestic practice, but for other purposes;

- expert method, when the threshold values are determined based on the opinions of the expert group;

- the determining method, when the value of the threshold values is established on the basis of the economic policy pursued to achieve certain goals.

The listed methods can be combined, since most threshold values are interrelated and interdependent. This interdependence is based on objective balance relations, which makes it possible to verify the calculations of the interconnection of individual threshold values.

\section{CONCLUSION}

Thus, relative to ensuring the social and economic security of the region the directions on formation of organizational, informational and methodical support for threats monitoring are determined.

According to the authors the following requirements should be submitted to the monitoring system:

1) Scientific substantiation of the evaluation indicators and their threshold values (Considering Regional Economic Interests, regional specifics and retrospective trends of market development and the ability to systematically assess).

2) Principles of monitoring (complex evaluation, systematic evaluation, adequacy of the assessment of the real situation, variant and operational impact on negative phenomena and processes).

3) Evaluation methodology (including mathematical apparatus and the opportunity of_combination of different approaches and methods of evaluation). 
4) Organizational and functional structure (Executive authorities at the regional and federal level and Scientific-research institutes and scientific-analytical organizations).

The use of monitoring results by regional authorities can allow:

1) identifying the threats to the regional alcohol market;

2) predicting the development of the situation as a result of the impact of identified threats;

3) to develop a set of measures to prevent possible or eliminate identified threats;

4) to form a system of rights and responsibilities; Mechanisms of interaction; A unified system of regulations for the recording of production, turnover of alcohol products, ensuring the level of quality and the system of public control.

\section{REFERENCES}

[1] World Health Organization [Electronic resource] - Access mode: http://www.consultant.ru (in Russian).

[2] On the strategy of the national security of the Russian Federation [Electronic resource]: Presidential Decree of December 31, 2015 № 683 // Reference legal system "ConsultantPlus". - Access mode: http://www.consultant.ru (in Russian).

[3] Raizberg, B. A., Lozovsky, L. Sh., Starodubtseva, E. B. Modern economic dictionary. $-6^{\text {th }}$ ed. - M.: INFRA-M, 2011 (in Russian).

[4] Lyapina, S. Yu., Ustich, D. P. Monitoring the implementation of innovative development programs at large Russian enterprises: monograph. - M.: Perot, 2014, 160 p. (in Russian).

[5] Katsik, D. E. Theoretical aspects of economic security of the region as a subject of foreign economic relations (on the example of the Krasnoyarsk Krai) / dissertation for the competition scientific degree of candidate of Economy. - Krasnoyarsk, 2003. (in Russian).

[6] The concept of the implementation of the state policy to reduce the abuse of alcohol and alcoholism among the population of the Russian Federation for the period until 2020 [Electronic resource]: approved by President of the Russian Federation // Reference legal system "ConsultantPlus". - Access mode: http://www.consultant.ru (in Russian).

[7] On the state regulation of production and turnover of ethyl alcohol, alcohol and alcohol-containing products and on the restriction of consumption (drinking) of alcohol products [Electronic resource]: feder. act of November 22, 1995 №171-FZ // Reference legal system "ConsultantPlus". - Access mode: http://www.consultant.ru (in Russian).

[8] Economic security of economic systems: textbook / A. V. Kolosov, V. I. Kushlin, A. N. Folomiev, E. A. Gryaznov / Ed. Prof. A. V. Kolosova. - M.: RAGS Publishing House, 2011. - 446 p. (in Russian). 